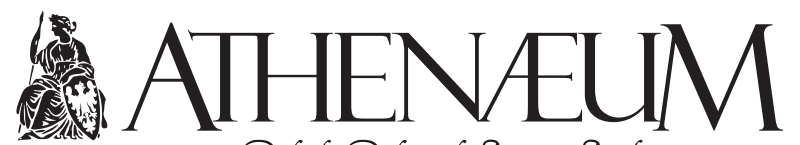

Polish Political Science Studies

Polskie Studia Politologiczne

vol. 63(3)/2019, pp. 156-168

DOI: 10.15804/athena.2019.63.10

www.athenaeum.umk.pl

ISSN 1505-2192

\title{
THE INFLUENCE OF CATHOLIC INTEREST GROUPS IN POLAND ON DRAFT LEGISLATION CONCERNING CIVIL UNIONS (2011-2014)
}

\author{
WPŁYW KATOLICKICH GRUP INTERESU W POLSCE \\ NA PROJEKTY USTAW DOTYCZĄCE ZWIAZZKÓW \\ PARTNERSKICH (2011-2014)
}

Krzysztof Kowalczyk* ()

\begin{abstract}
The main purpose of this article is to demarcate the influence of Catholic interest groups in Poland on the attempts to introduce legislation that would regulate the legal status of civil unions. Catholic interest groups are defined as an association of individuals, organisations or institutions which articulate postulates of the Catholic Church. In order to fulfil their agendas, these groups, especially pro-life groups, apply various methods of lobbying, persuasion or moral sanction. The article includes the author's own typology of influence of these groups on political institutions and their environment. Selected methods of influence were applied during debates in the Sejm on the draft bills concerning legalization of civil unions, including those between people of the same sex. Catholic interest groups opposed those regulations.
\end{abstract}

Keywords: Catholic interest groups; civil unions; legislation; Poland
Głównym celem artykułu jest określenie wpływu katolickich grup interesu w Polsce na próby wprowadzenia ustawodawstwa regulującego status związków partnerskich. Katolickie grupy interesów są definiowane jako zrzeszenia jednostek, organizacje lub instytucje artykułujące postulaty Kościoła katolickiego. W celu realizacji swoich zamierzeń grupy te, zwłaszcza pro-life, stosują różnorodne metody lobbingu, zabiegi perswazyjne i sankcje moralne. W artykule zawarto autorską typologię oddziaływania tych grup na instytucje polityczne i ich otoczenie. Wybrane formy działania zastosowano podczas debat w Sejmie na temat projektów ustaw legalizujących związki partnerskie, także osób tej samej płci. Katolickie grupy interesu opowiadały się przeciwko wprowadzeniu tych regulacji.

Słowa kluczowe: katolickie grupy interesu; związki partnerskie; legislacja; Polska

\footnotetext{
* University of Szczecin, Faculty of Humanities.
} 


\section{INTRODUCTION}

The primary objective of this article is to analyse the influence of Catholic interest groups in Poland on the attempts to introduce legislation that would regulate the legal status of civil unions. Therefore, the following secondary objectives were established: to specify the role of the Catholic Church in Poland and its impact on the political process; to define the concept of a Catholic interest group and the ways they influence political institutions; to offer a synthesis of the issue of the legalization of civil unions in 2011-2014; to present the attitude of the Catholic Church to this issue and to analyse the way Catholic interest groups influenced the attempts to block the draft legislation concerning civil unions.

A civil union is defined as a legally recognized civil relationship of two people of any sex. For this reason, a civil union may be created by two people of the same sex. The term "Catholic Church", in a general sense, represents the community of believers - a group of believers who commit to live according to the teachings of the religion. In a strict sense, the Church is an institution whose mission is mostly of a spiritual and religious character. However, institutional Church, by its ideological teachings, has an impact on human life and public order. The mission of the Church is inevitably a political action (Böckenförde, 1992, pp. 92-93). Thereby, the Church participates in political process. The institutional Church is in this text also synonymously called the "hierarchical Church". The hierarchical structure of the Church, resulting from ordination, is made of bishops, priests (presbyters), and deacons. Bishops shape Catholic Social Teaching by issuing pastoral letters, giving homilies and interviews. On the Polish territory, the bishops are gathered in the Episcopal Conference of Poland. This organization issues documents which complement Catholic Social Teaching in a form of pastoral letters, statements or announcements and undertakes a dialogue with political authorities (Delong, 2016, pp. 17-43).

Systems analysis methods were used to describe the influence of the typology of the Catholic Church and related interest groups. Institutional and legal method was used to analyse the draft legislation submitted to the Sejm. Case study method has been applied to illustrate the impact of the Catholic interest groups on the legislation process concerning the aforementioned issue. The timeframe of this study was established by the period of intense work on the draft legislation concerning civil unions in the Sejm (2011-2014). The issue of legalization of civil partnerships in Poland has not been of interest to the scholars of political studies. So far, what has been studied is the influence of 
religious beliefs and of the Catholic Church on the attempts to introduce the laws concerning civil unions (Hennig, 2010, 2012, pp.303-307; Kowalczyk, 2015) and the attitude of the political parties towards this issue (Tomczak, 2012; Zawadzka, 2016; Zawadzka \& Tomczak, 2018).

\section{THE ROLE OF THE CATHOLIC CHURCH AND ITS INFLUENCE ON THE POLITICAL PROCESS}

After 1989, the Catholic Church has played a crucial role in the public life in Poland. The Church, articulating its perspective on specific political and social issues, has participated in the political process. The Church joined the sphere of politics, legitimizing particular political parties, supporting them in implementation of specific draft bills (Lipiński, 2016, pp. 52-55). The position of the Catholic Church results from historical and political factors, the accepted model of religious relations and almost homogenous religious structure

The Catholic Church in Poland is undoubtedly a subject influencing the political process. In political studies, it is also described as an institutional group of interests, an untypical political actor. In order to meet its political postulates, resulting from Catholic Social Teaching, the Church influences political institutions (political parties or authorities), the media and society. The forms of influence applied by the Catholic Church are typical for lobbying and may be of persuasive character (a public prayer) or that of a moral sanction (positive ones, e.g., praising a politician, or negative ones, e.g., threatening a policymaker with excommunication). In case of classic advocacy, the methods used are direct and indirect. In the former, bishops influence policy-makers directly (via, e.g., meetings, conversations, letters, statements), in the latter, however, they use particular subjects as intermediaries. Institutional Church articulates its postulates through the agency of its specialized bodies, the media, trade unions of a Catholic provenience (e.g., the Independent Self-Governing Trade Union "Solidarnośc'), common Church and state bodies (the Common Committee of the Polish State and Polish Bishops' Conference), experts, appeal to the public opinion (in forms of demonstrations or petitions), and interest groups (Kowalczyk, 2015, pp. 62-67). 


\section{CATHOLIC INTEREST GROUPS AND THEIR IMPACT ON THE POLITICAL INSTITUTIONS}

As it has been mentioned, the Catholic Church articulates its postulates also by means of related interest groups. Konrad Oświecimski describes an interest group as an association of individuals or institutions that are subject to the public authority which, on the basis of internally shared values, attempts to actively influence the shape of public politics, although it does not aim to formally wield power (Oświecimski, 2012, pp. 43-44). Interest groups, by endorsing their postulates, have an impact on political institutions (authorities or political parties). In Italy, the preferred term is "pressure groups", as they are subjects with influence on political life. The Italian Catholic Action belongs to the category of the pressure group of the Church (La Palombara, 2015, pp. 6-9). The term "interest groups" is undoubtedly narrower than religious interest groups or political subjects referring to values. According to Caelesta Braun-Poppelaars and Marcel Hanegraaff, the term "religious interest groups" refers to various organisations which are focused on cooperation with policy-makers; they represent a group of norms and values imposed by preternatural and abstract beings whose existence is treated as a given (Braun-Poppelaars \& Hanegraaff, 2011, p. 153). In this article, I refer to the concept of Catholic interest groups, that is, associations of individuals, organisations or institutions which articulate the postulates of the Catholic Church. These groups are natural allies of the hierarchical Church in their actions to implement preferred norms and values, resulting from Catholic Social Teaching, into the state legislation. In this regard, these groups are engaged in religious advocacy, lobbying for the Catholic Church (Knutson, 2015, pp. 3585-3599). However, Catholic groups are dependent on the Church to varying extents. Some of the interest groups mentioned above may work within the structures of the Church -ecclesial groups, and some may be outside of it - non-ecclesial groups. The ecclesial groups in Poland include Catholic non-governmental organisations (e.g., the Catholic Association of Polish Doctors), Church institutions (the National Council of Lay Catholics), religious movements (the Light-Life Movement), and groups of believers. Ecclesiastical groups are established with the consent of the relevant Church authority and they have an appointed ecclesiastical assistant. The non-ecclesiastical groups comprise of non-governmental organisations sensu stricto - associations and foundations (e.g., the Polish Association of the Guardians of Human Life, the "Voice for Life" Foundation), trade unions (the Independent Self-Governing 
Trade Union "Solidarność"), or informal associations. In this connection, it should be stressed that the Catholic interest groups, also called "pro-Church" groups, are very diverse in terms of their dependence on the Catholic Church, their formal and legal organisation, types of memberships, territorial scope or their goals (Kowalczyk, 2017).

The purpose of Catholic interest groups is to promote the doctrine and teaching of the Catholic Church. An important role among those subjects is played by the pro-life groups. Pro-life groups are engaged in activities which promote a Catholic model of marriage and family and implement the rules of Catholic Social Teaching in state legislation. The objectives of pro-life groups are, in particular, to introduce a complete human embryo protection (stricter anti-abortion laws); supporting pregnant mothers and families (especially single mothers and multi-child families); dissemination of natural family planning methods; criticism and postulating a total ban on contraceptive measures (especially morning-after pill); objecting to the in vitro procedures of artificial insemination and to the legalization of civil unions and same-sex marriages.

In order to realise their postulates, pro-life groups - like the hierarchical Church - use various methods of advocacy. Some of them are typical lobbying, while others exceed the classic concept of advocacy (see: Jasiecki, MolędaZdziech, \& Kurczewska, 2006). An analysis of the activities of pro-lifers since 1989 shows that the characteristic direct methods of lobbying were conversations with representatives of public authorities (Members of the Parliament, the government members, judges) on the necessity to introduce specific regulations. Pro-life activists made their position heard during press conference or works of the parliamentary committees (Cymanow-Sosin, 2015). They also used a wide spectrum of advertisement and visual, audio-visual or Internet promotion. In regard of the direct lobbying, demonstrations in front of the Sejm and picquets were most often used. An example of a happening aimed to increase public awareness in terms of protection of human life from its conception was to give away figurines representing an embryo (a child in a mother's womb). Petitions and letters were also written and sent to policy-makers, asking to support specific postulates. Since 2006, a March for Life is organised in many cities. As a result of the $293^{\text {rd }}$ resolution of the Plenary Meeting of the Polish Bishops' Conference, 25 March is celebrated in the Catholic Church as the Day of the Holiness of Life. On the other hand, since 2004, 24 March is celebrated in Poland as a National Day of Life, as proclaimed by the Sejm. The standard form of operation of the prolife groups is their media presence, referring to experts (medical professionals, 
psychologists, or lawyers). These organizations also use methods which exceed classic lobbying. The persuasive methods include, in this respect, public prayers led by the pro-lifers. Moral sanctions are to encourage people to behave in ways that are accepted according to the values shared by pro-life groups. Moral sanctions may be positive - praising those politicians and citizens who vote according to the regulations of the Catholic Social Teaching, or negative - for those who opt against this teaching (e.g., support liberalization of the anti-abortions laws). A comparison of methods used by pro-life groups in Poland is depicted in Table 1. Some of the methods mentioned there have been used during the debate on legalization of civil partnerships in Poland.

Table 1. Methods Used by Pro-Church Interest Groups Engaged in Pro-Life Activism

\begin{tabular}{|c|c|c|c|c|}
\hline \multicolumn{2}{|l|}{ Direct lobbying } & \multirow{2}{*}{ Indirect lobbying } & \multirow{2}{*}{ Persuasion } & \multirow{2}{*}{ Sanctions } \\
\hline oral & written & & & \\
\hline $\begin{array}{l}\text { - meetings with } \\
\text { policy-makers; } \\
\text { - public } \\
\text { appearances; } \\
\text { - press } \\
\text { conferences; } \\
\text { - participating } \\
\text { in the work of } \\
\text { parliamentary } \\
\text { committees. }\end{array}$ & $\begin{array}{l}\text { - statements; } \\
\text { - letters; } \\
\text { - emails; } \\
\text { - academic } \\
\text { texts; } \\
\text { - booklets; } \\
\text { - photographs; } \\
\text { - leaflets; } \\
\text { - posters; } \\
\text { - billboard } \\
\quad \text { advertise- } \\
\quad \text { ments; } \\
\text { - films; } \\
\text { - video clips. }\end{array}$ & $\begin{array}{l}\text { - manifestations and } \\
\text { picquets in front of } \\
\text { the Parliament; } \\
\text { - pro-life happenings; } \\
\text { - petitions; } \\
\text { - sending letters to } \\
\text { politicians and } \\
\text { authorities; } \\
\text { - a March for Life and } \\
\text { Family; } \\
\text { - the Day of the } \\
\text { Holiness of Life; } \\
\text { - interviews in the } \\
\text { media; } \\
\text { - academic conferences; } \\
\text { - referring to experts. }\end{array}$ & $\begin{array}{r}\text { - public } \\
\text { prayer. }\end{array}$ & $\begin{array}{l}\text { Positive: } \\
\text { - Praising politicians } \\
\text { who opt for regula- } \\
\text { tions in accordance } \\
\text { to the Catholic Social } \\
\text { Teaching; } \\
\text { Negative: } \\
\text { - Stigmatising } \\
\text { politicians. }\end{array}$ \\
\hline
\end{tabular}

Source: author's own elaboration.

\section{DRAFT LEGISLATIONS ON CIVIL UNIONS}

Draft legislations on civil unions were submitted to the Sejm several times since 2003. In 2011, a draft bill on civil unions was submitted by the politicians from the Democratic Polish Alliance (SLD) and the Campaign Against Homophobia. It concerned both heterosexual and homosexual couples. In this draft bill, 
a civil union was understood to be an agreement of two legal persons, effectively cohabitating, who establish their mutual financial and personal obligations in order to organise their life together. A civil union would be established in the Registrar's Office and could be dissolved by a statement of intent. It was assumed that a civil union would be equal to marriage in terms of tax, inheritance, housing and pension laws. The draft bill was not considered in the Sejm of the $4^{\text {th }}$ term.

After the parliamentary elections in 2011, the Democratic Polish Alliance, Palikot's Movement/Your Movement and a group of MPs from the Civic Platform each submitted their own draft bills. All three draft bills submitted in 2012 referred to couples of both sexual orientations. They postulated that civil union agreements would be made in the presence of the Director of the Registrar's Office (according to the Democratic Polish Alliance), a notary (Palikot's Movement) or, alternatively, both (the Civic Platform). Generally speaking, each of them stipulated the right to inherit property and alimony obligation to support the partner living in poverty. During the meeting of the Sejm on 24 January 2013, a division within the Civic Platform became evident: the Minister of Justice, Jarosław Gowin, deemed all three draft bills as contrary to Article 18 of the Constitution. The Prime Minister Donald Tusk stated that Minister Gowin was expressing his own private opinion. A day later, all three draft bills were rejected.

In 2013, more draft bills were submitted by the MPs from the Democratic Polish Alliance and Your Movement, and they concerned both heterosexual and homosexual couples. In both draft bills it was stipulated that a couple would express a statement of intent in front of the Director of the Registrar's Office. Establishing a community property was also possible. During the Sejm meeting on 17 December 2014, it was decided that the draft bill submitted by Your Movement would not be included into the agenda of the meeting, while on 26 May 2015, the same was done regarding the draft bill proposed by the Democratic Polish Alliance.

During parliamentary debates, the proponents of legalization of civil unions (the Democratic Polish Alliance, Palikot's Movement/Your Movement, the liberal branch of the Civic Platform, Labour Union) were referring to the ideals of human rights, equality and European legislation. The opponents (Law and Justice, United Poland, Polish People's Party and the conservative branch of the Civic Platform) considered homosexual relationships as a threat to the stability of a traditional family and moral order. The activities of conservative politicians were legitimized and supported by the Catholic Church (Kowalczyk, 2015, pp. 67-71). 


\section{THE POSITION OF THE CATHOLIC CHURCH}

The Catholic Church has consistently opposed legalization of civil unions, in particular those of same-sex couples (Delong, 2016, pp. 339-343). The Catholic Church has seen marriage as a sacramental union of a woman and a man. Sexual activity between people of the same sex is viewed as a sin. In the document issued in 2003 by the Congregation for the Doctrine of the Faith, titled "Considerations Regarding Proposals to Give Legal Recognition to Unions Between Homosexual Persons", it has been stated that " $\mathrm{t}$ ] here are absolutely no grounds for considering homosexual unions to be in any way similar or even remotely analogous to God's plan for marriage and family. Marriage is holy, while homosexual acts go against the natural moral law" (Kongregacja..., 2003). Polish bishops also stressed that the draft legislation concerning legalization of civil unions are incompatible with the Article 18 of the Constitution, which stipulates that marriage is a relationship of a woman and a man, and states that, along a family, motherhood and parenthood, marriage is under protection and preservation by the Republic of Poland. The Church hierarchs appealed for society to resist "deconstruction of the family". Their argument was that, according to public opinion, the majority of Poles was against legalisation of civil partnerships (Kowalczyk, 2015, pp. 73-74).

As a result, the Church hierarchs appealed to political policy-makers in attempt to stop legalisation of civil unions. During the $335^{\text {th }}$ Plenary Meeting of the Polish Bishops' Conference on 16 June 2011, the bishops addressed politicians, asking them not to give in to the pressures of the groups aiming at equalling marriage between a woman and a man to civil partnerships of people of the same sex (Komunikat..., 2011). In January 2013, the Head of the Episcopal Council of the Family, bishop Kazimierz Górny, in his letter to the Marshal of the Sejm, Ewa Kopacz, expressed his gratitude and appreciation to those MPs who voted against draft legislation concerning this issue (Rada KEP..., 2013). The bishops, aiming at blocking draft bills regulating civil partnerships, used various method to influence political institutions, including the mediation of interest groups that are linked to the Church. 


\section{CATHOLIC INTEREST GROUPS AND ATTEMPTS TO INSTITUTIONALISE CIVIL UNIONS}

Catholic interest groups, as natural allies of the Church, used selected forms of lobbying, persuasion and moral sanction in order to articulate their negative attitude and to reject the draft legislation on civil unions. Among the advocacy activities were appeals to politicians, sending letters, giving away leaflets, manifestations, referring to reports and authorities.

In August 2011, members of the Family Issues Team in the Common Committee of the Polish State and the Polish Bishops' Conference, linked to the Polish Federation of Pro-Life Movements (Joanna Krupska, Antoni Szymański, Paweł Wosicki), in their letter Sławomir Piechota, the head of the Family and Social Policy Committee in the Sejm, stressed that the draft bill on the civil unions "goes against constitutional guarantee to protect marriage, family, motherhood and parenthood", included in the Article 18 (Projekt ustawy..., 2011). In December 2011, the Mum and Dad Foundation called to send a letter to the Prime Minister Donald Tusk (the Civic Platform) in light of the announcement made in his expose in the Sejm that laws equalizing marriages and civil partnerships need to be introduced (Wyślij list..., 2011). In January and February 2013, an appeal to the MPs of the Sejm asking them to reject the draft bills submitted by the Democratic Polish Alliance, Your Movement and the Civic Platform was made by the Polish Federation of Pro-Life Movements, the Association of Catholic Women, the Catholic Intelligentsia Club in Warsaw, and the Catholic Action. In a statement made by the Federation, it was said that draft legislations aiming at awarding a similar status to every adult couple, including a same-sex one, will destroy marriage. Halina Szydełko, the Head of the National Board of the Catholic Action, stated that all three draft bills are "part of the same ideological project which aims at destroying the heritage and identity of Europe as founded on Christian values, among which the family has been the foundation of social life" ("Związki...", 2013).

In February and March 2013, the Father Piotr Skarga Association of Christian Culture organized an event of collecting signatures under a petition for the Prime Minister Donald Tusk against draft legislation concerning civil unions, submitted by the Democratic Polish Alliance and Your Movement. In the letter to the Prime Minister, it was stated that "such draft bills are discriminating against Polish families and marriage, as they make them equal to deviant forms of behaviour, which by no means can become a foundation for the one basic 
social cell, a family" ("NIE dla...", 2013). This event took place on the Internet, as well as in "door-to-door" method, when leaflets were given away to the citizens of Warsaw. The information and protest campaign against legalisation of civil partnerships was also held in December 2012 by the Crusade of the Youth. Members of this Catholic organisation handed out leaflets in Wrocław, Łódź, Piotrków Trybunalski, and Warsaw. An integral part of this event was a rosary prayer said "to apologise for the public manifestation of the sin of homosexuality" (Krucjata Młodych..., 2013) The actions undertaken by the Crusade crossed the lines of traditional lobbying, as the persuasive measure of prayer was applied.

In 2012, the activists from the Polish Federation of Pro-Life Movements called the public to take part in the March “Wake up, Poland!", to defend, among other things, the Polish family. The draft bill on civil unions, submitted by a group of MPs from the Civic Platform, was given an example of governmental policies against marriage and family. On 10 March 2013 in Gdańsk, a confrontation between the proponents and opponents of legalisation of civil partnerships took place. Nationalist organisations, the National Radical Camp and the All-Polish Youth, were among the organisers of this march. The banners included such phrases as: "A normal family is a girl and a boy", or: "Marriage - Life - Family YES!!!” (OBUDŹ SIĘ POLSKO..., 2012). Another march took place in Gdańsk on 5 May 2013. After a mass said by archbishop Sławoj Leszek-Głódź in St. Bridget Church, a crowd marched to the monument of Jan Sobieski; among them were, e.g., politicians from the Law and Justice party, activists from "Solidarność", diocese groups of "Radio Maryja", members of the Rosary Crusade and the Catholic Association "Civitas Christiana". At the head of the march, a banner said, "Stop homodictate. A girl and a boy make a family" (Marsz..., 2013).

An important element of the campaign against legalisation of civic partnerships were statements by bishops and scholars made in the press: priest prof. Piotr Mazurkiewicz, Father Józef Augustyn, prof. Urszula Dudziak. Father Augustyn suggested that the next step will be to postulate that children may be adopted by same-sex couples, and added: "one may proclaim anything if they have the majority in the Parliament, but it is not a parliament that decides who can have children and what gender would a mother and a father be".

A letter of thanks, written for the 228 MPs who voted against the draft bills on civil unions on 25 January 2013, was a form of support for the politicians opposing legalization of civil partnerships (Rada KEP..., 2013). This form is part of the category of a positive moral sanction. 


\section{CONCLUSIONS}

The Catholic Church in Poland, in order to articulate its postulates, refers to the mediation of associated interest groups described as pro-Church or Catholic. Institutional Church is for those subjects somewhat of an external, sponsoring institution. This means that, 1 ) these groups may be created by direct inspiration from the Holy See, the Episcopal Conference of Poland, bishops in dioceses (Church interest groups); 2) their activity is usually legitimised by the Catholic clergy.

Catholic interest groups are in Poland political actors, affecting political institutions. Pro-life groups are an important category among them. At the centre of their attention is the so-called protection of life, including restrictive anti-abortion laws, promoting Catholic, traditional model of marriage as a sacramental union of a woman and a man. Their influence on the political process is characteristic for typical lobbying, is of a persuasive character or has a form of moral sanctions. An example of this claim is their influence on the attempts to legalise civil unions. Pro-life groups, contesting initiatives that aimed at legal sanctioning of homosexual and heterosexual couples, referred to selected forms of influencing political actors, the media and society, while the main power of their protest was aimed at institutionalization of same-sex partnerships. Pro-life groups were, to some extent, a transmission of the institutional Church in the realization of its doctrine.

The main purpose of this article was to demarcate the influence of Catholic interest groups in Poland on the attempts to introduce legislation that would regulate the legal status of civil unions. Catholic interest groups are defined as an association of individuals, organisations or institutions which articulate postulates of the Catholic Church. In order to fulfil their agendas, these groups, especially pro-life groups, apply various methods of lobbying, persuasion or moral sanction. The article included the author's own typology of influence of these groups on political institutions and their environment. Selected methods of influence were applied during debates in the Sejm on the draft bills concerning legalization of civil unions, including those between people of the same sex. Catholic interest groups opposed those regulations. 


\section{REFERENCES:}

Böckenförde, E.W. (1992). Wolność - państwo - Kościót. Kraków: Wydawnictwo Znak. Braun-Poppelaars, C., \& Hanegraaff, M. (2011). Conceptualizing Religious Advocacy: Religious Interest Groups and the Process of Public Policy Making. In: J. Haynes, \& A. Hennig (eds.). Religious Actors in the Public Sphere: Means, Objectives, and Effects (pp. 132-148). London-New York: Routledge.

Cymanow-Sosin, K. (2015). Strategia zarządzania kampanią na przykładzie przekazów audiowizualnych ruchu pro-life. Studia Socialia Cracoviensia, 7(2), 11-23.

Delong, M. (2016). Konferencja Episkopatu Polski wobec wybranych kwestii politycznych i społecznych w Polsce w latach 1989-1914. Rzeszów: Wydawnictwo Uniwersytetu Rzeszowskiego.

Hennig, A. (2010). Morality Politics in a Catholic Democracy: A Hard Road towards Liberalisation of Gay Rights in Poland. In: J. Haynes (ed.). Religion and Politics in Europe, the Middle East and North Africa: Secularisation, Democracy and Citizenship (pp. 202-226). London: Routledge/ECPR.

Hennig, A. (2012). Moralpolitik und Religion. Bedingungen politisch-religiöser Kooperation in Polen, Italien und Spanien. Würzburg: Ergon-Verlag.

Jasiecki, K., Molęda-Zdziech, M., \& Kurczewska, U. (2006). Lobbing. Sztuka skutecznego wywierania wplywu. Kraków: Oficyna Ekonomiczna.

Knutson, K. (2015). Interfaith Advocacy Groups in American Politics. In: S.D. Brunn (ed.). The Changing World Religion Map: Sacred Places, Identities, Practices and Politics (pp. 3585-3600). Dordecht: Springer Netherlands.

Komunikat $z$ 355. Zebrania Plenarnego Konferencji Episkopatu Polski. LicheńWłocławek, 26 czerwca 2011 r. (2011). Retrieved from: https://episkopat.pl/ komunikat-z-355-zebrania-plenarnego-konferencji-episkopatu-polski/.

Kongregacja Nauki i Wiary (2003). Uwagi dotyczace projektów legalizacji zwiazków między osobami homoseksualnymi. Rzym, 3 czerwca 2003 r. Retrieved from: http:// www.vatican.va/roman_curia/congregations/cfaith/documents/rc_con_cfaith_ doc_20030731_homosexual-unions_pl.html.

Kowalczyk K. (2015). Kościół rzymskokatolicki w Polsce jako podmiot oddziałujący na system polityczny. Casus ustawy o związkach partnerskich. Colloquium, 4, 61-82.

Kowalczyk, K. (2016). Między antyklerykalizmem a konfesjonalizacja. Partie polityczne wobec Kościoła katolickiego w Polsce po 1989 roku. Toruń: MADO.

Kowalczyk, K. (2017). Typologia grup interesu artykułujących postulaty Kościoła katolickiego w Polsce. Przeglad Politologiczny, 2, 177-188. DOI: 10.14746/ pp.2017.22.2.11.

Krucjata Młodych przeciwko związkom partnerskim (2013). Retrieved from: https:// www.pch24.pl/krucjata-mlodych-przeciwko-zwiazkom-partnerskim,19793,i.html.

La Palombara, J. (2015). Interest Groups in Italian Politics. Princeton: Princeton University Press. 
Lipiński, A. (2016). Prawica na polskiej scenie politycznej w latach 1989-2011. Historia, organizacja, tożsamość. Warszawa: Dom Wydawniczy ELIPSA. Marsz w obronie rodziny (2013). Retrieved from: https://ekai.pl/marsz-w-obronie-rodziny/.

"NIE dla związków partnerskich". Podpisy złożone w Kancelarii Premiera (2013). Retrieved from: https://www.piotrskarga.pl/-rdquo-nie-dla-zwiazkow-partnerskich-rdquo---podpisy-zlozone-w-kancelarii-premiera,10429,i.html.

OBUDŹ SIĘ POLSKO. Marsz 29.09 br. Warszawa (2012). Retrieved from: http://federacjazycia.pl/pg/pl/wiadomosci/obudz_sie_polsko_marsz.html.

Oświecimski, K. (2012). Grupy interesu i lobbing w amerykańskim systemie politycznym. Kraków: Wydawnictwo WAM.

Projekt ustawy o związkach partnerskich sprzeczny z Konstytucja RP (2011). Retrieved from: http://federacjazycia.pl/pg/pl/wiadomosci/projekt_ustawy_o_zwiazkach. html.

Rada KEP ds. Rodziny dziękuje posłom (2013). Retrieved from: https://www.deon.pl/ religia/kosciol-i-swiat/z-zycia-kosciola/art,13146,rada-kep-ds-rodziny-dziekujeposlom.html.

Tomczak, Ł. (2012). Problem legalizacji związków partnerskich osób tej samej płci w kampanii wyborczej 2011 roku. Preferencje Polityczne. Postawy - identyfikacje -zachowania, 1(3), 237-249. DOI: 10.6084/m9.figshare.94198.

Wyślij list do Premiera - NIE dla zrównania konkubinatów z małżeństwami! (2011). Retrieved from: http://www.mamaitata.org.pl/wiadomosci/wyslij-list-do-premieranie-dla-zrownania-konkubinatow-z-malzenstwami.

Zawadzka, K. (2016). Związki partnerskie mniejszości seksualnych w programach polskich partii politycznych. Acta Politica Polonica, 1, 49-57. DOI: 10.18276/ ap.2016.35-04.

Zawadzka, K., \& Tomczak, Ł. (2018). Polskie partie polityczne i ich wyborcy wobec związków partnerskich osób tej samej płci. Polityka i Społeczeństwo, 1, 132-145. DOI: 10.15584/polispol.2018.1.10.

"Związki partnerskie sa nie do przyjęcia” (2013). Retrieved from: https://m.deon.pl/ religia/kosciol-i-swiat/z-zycia-kosciola/art,13071,zwiazki-partnerskie-sa-nie-doprzyjecia.html. 